\title{
An annotated bibliography of the Mohenjodaro studies in the Pakistani research journals
}

\author{
Sirat Gohar ${ }^{1}$ | Ifqut Shaheen*2 | Anura Manatunga ${ }^{3}$ \\ 1. National Institute of Folk and Traditional Heritage (Lok Virsa), Islamabad, Pakistan. \\ 2. Department of History, Shaheed Benazir Bhutto Women University, Peshawar, Pakistan. \\ 3. Department of Archaeology, Government of Sri Lanka, Colombo, Sri Lanka. \\ *Corresponding Author Emails: ifqatmahr@gmail.com | ifqutshaheen@ sbbwu.edu.pk
}

\begin{abstract}
The publication of archaeological research is one of the important jobs the archaeologists should do. "Excavation without publication is destruction" is a famous axiom in archaeology. Once an archaeological site is exposed, it could not be restored despite the fact if the structures are conserved. Archaeologists aim to share as well as popularize archaeological discoveries and it necessitates the publication of results. Such endeavours result in preliminary reports, final reports, books, guidebooks, conference proceedings, scholarly articles in research journals, and popular articles in magazines and newspapers. All such forms of knowledge production and dissemination help archaeologists reach the target audience. Especially, research journal articles are primarily intended for specialists. This study focuses on the papers published on Mohenjodaro in Pakistani research journals (English). The study aims to prepare an annotated bibliography of the papers published on Mohenjodaro and place them in a broader perspective of the Indus Civilization. This research discovers that a total of 53 papers, which include reports of archaeological excavations, surveys, and conservation and preservation of monuments, research articles, a poem, and a book review, have been published on Mohenjodaro in Pakistani journals dedicated to archaeology, history, culture, and literature.
\end{abstract} Article History

Received:

March 10, 2021

Last Revised:

June 20, 2021

Accepted:

June 23, 2021

Published:

June 30, 2021

Keywords: Mohenjodaro, archaeology, archaeological research, annotated bibliography, research paper, research journal, research article, popular article, Indus Civilization.

How to Cite: Gohar, S. Shaheen, I., \& Manatunga, A. (2021). An annotated bibliography of the Mohenjodaro studies in the Pakistani research journals. Liberal Arts and Social Sciences International Journal (LASSIJ), 5(1), 686-708. https://doi.org/10.47264/idea.lassij/5.1.44

Publisher's Note: IDEA PUBLISHERS (IDEA Journals Group) stands neutral with regard to the jurisdictional claims in the published maps and the institutional affiliations.

Copyright: () 2021 The Author(s), published by IDEA PUBLISHERS (IDEA Journals Group). This is an Open Access article published under the Creative Commons Attribution-NonCommercial 4.0 International License (http://creativecommons.org/licenses/by-nc/4.0/) 


\section{Introduction}

Mohenjodaro, an important city of the Indus civilization, is an archaeological site in Pakistan that has remained a significant site for archaeologists and other scholars to explore (Fig. 1). Scholars have estimated that only $10 \%$ of the total area of the site has been excavated so far. However, further excavation at the site is not possible due to the high level of the water table and 'the problems of conserving exposed structures and weathering' (Kenoyer, 2005). The last time it was in 1964-65 when George. F. Dales removed the soil, but the rising water level restrained him to dig deeper. This does not mean that the archaeological work at Mohenjodaro has ceased. Activities concerning conservation, rehabilitation, and promotion of the site never stopped. Moreover, earlier field activities at the site have revealed archaeological material in abundance that has been studied by scholars from all around the world. Both Pakistani and foreign researchers have been part of Mohenjodaro studies. As a result, a substantial literature has been published so far. It consists of books, guides, articles, pamphlets, and brochures. As far as the articles on Mohenjodaro are concerned, they have been published in newspapers, magazines, and research journals. This study focuses on the articles published on Mohenjodaro in Pakistani research journals (English). This study aims to prepare an annotated bibliography of the Mohenjodaro papers ${ }^{1}$, which are published in different journals dedicated to archaeology, history, Pakistan studies, and literature (Appendix-I).

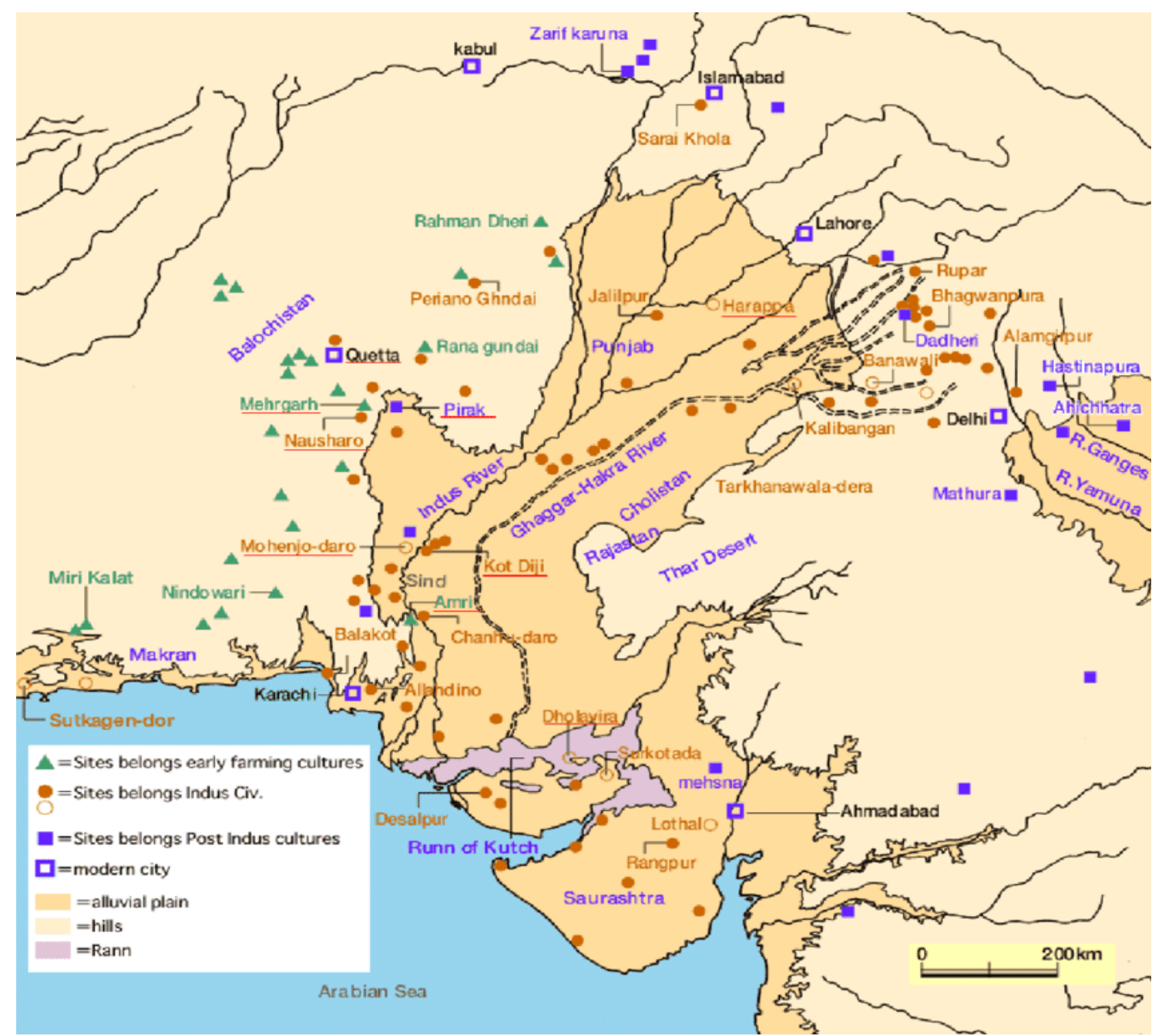

Figure 1. Map of the Indus Civilization (Tokai University, 2000). 
There are various perspectives on the Indus Civilization. Famous ones are those of the first excavators of Harappan sites (e.g., Marshall, 2012; Mackay, 2001, 1997; Wheeler, 1997). However, discoveries of Harappan sites made new additions to its knowledge and have greatly affected the older paradigms therefore much is proven invalid, and some are replaced by new ideologies. Despite this, contemporary writings are not exempted from those old paradigms (Possehl, 2002, p. 247). Especially in the case of writings on Mohenjodaro published in Pakistani journals, one can notice the touch of older concepts. Most of these articles on Mohenjodaro that are deemed as the outcome of new research are not free from earlier writings and some of these papers are reproduced from previously published works. However, this study presents a historiographical account of Mohenjodaro papers (studies) and attempts to place them in a broader perspective of the Indus Civilization.

\section{Research methodology}

This study offers an annotated bibliography of the articles published on the Mohenjodaro studies in Pakistani research journals. All the papers included in this study have been collected from different Pakistani educational institutions, publishing section of the Federal Department of Archaeology and Museums (DOAM), and website of the Sindh Antiquities, which is a research journal of the Department of Culture, Tourism, Antiquities, and Archives, Government of Sindh, Pakistan. A special focus had been on the selection of papers; it was a difficult task for the researchers as many papers written on the Indus civilization have mentioned Mohenjodaro. Due to this reason preparing an annotated bibliography of the works about Mohenjodaro vexed us as to what to be included or excluded. For this, by carefully analysing the articles on the Indus Civilization, an effort was made to select closely relevant text to Mohenjodaro.

A total of fifty-three papers (articles, reports, book review, and a poem) have been selected from twelve journals of history, archaeology, and literature, and have been included for analysis in this study (see Appendix-I). These papers cover various aspects of Mohenjodaro such as topography, discovery and fieldwork, nomenclature, urban planning, script, religion, trade relations, and decline. The annotations highlight the importance and nature of these studies. To make it simple and comprehensible, all the papers have been enlisted in alphabetical order and arranged according to the date of their publication following a sequence that is old to new. However, the acronyms of the names of places (e.g., libraries, publishing sections, and websites), where the journals are available have been mentioned at the end of each reference for the convenience and easy access of readers (see appendix-II for the list of abbreviation). However, the articles published in the Sindh Antiquities were downloaded from the website of the journal.

\section{An annotated bibliography}

a) Ahmad, M. (1994). Moenjodaro: Heritage of Mankind. Lahore Museum Bulletin, VII(12), 301. LML.

This is a positive review of Ihsan H. Nadeem's book Moenjodaro: Heritage of Mankind.

b) Ahmad, W. (1991). Restoration of a Bronze Cooking Pot from Mohenjodaro. Lahore Museum Bulletin, IV(1), 81-83. AHDL. 
Lahore museum has a good collection of Indus objects. Some of them including the Bronze Cooking Pot, the subject of this study, were taken from Mohenjodaro. The Pot was broken into pieces by a worker during a distemper work in the Indus Gallery. And soon after that, it was restored. This paper provides the detail of the restoration of the Pot. Photographs of the Pot are also given at the end of the paper.

c) Ahmad, S. Q. (1981). The Lost Cities of Sind: A study of some aspects of Past Urbanization in Sind. The Grassroots, V(I-II), 1-8. CLUS.

The causes of the disintegration of the ancient cities of Sindh have been discussed in this paper. Particularly, about the decline of Mohenjodaro, the author writes that recurring floods in the Indus River and intrusion of barbarians were the main causes of its decline. The Mohenjodaro section of this article is reproduced from earlier works. What the author has incorporated in this article is already known from previously published works.

d) Allchin, F. R. (1993). A Masterpiece from the Indus Civilization. Pakistan Archaeology, 29, 217-229. DOAM.

Back in the 1920s and the early 1930s during the British rule in India, the artifacts of the Indus Civilization were transported in numbers to Western Countries. One such object from the Indus Valley traveled to Hoshang Mahboubian - an antiquity dealer and collector from London. It was a small sculpture of a ram made of metamorphosed limestone. It is the subject of Allchin's investigation in this study. In this study, the author has formulated a hypothesis that the Mahboubian $\mathrm{ram}^{2}$ belongs to Mohenjodaro. This paper was presented on the occasion of the International Symposium on Moenjodaro-1992 held in Karachi. This very important work by Allchin identified the lost antiquity of Mohenjodaro. Allchin is highly credited for his research on archaeology and the civilizational history of India and Pakistan.

e) Ardeleanu-Jansen, A. (1988). The Terracotta Figurines from Mohenjo-Daro: Considerations on Tradition, Craft and Ideology in the Harappa culture. Lahore Museum Bulletin, I(2), 9-28. AHDL.

Indus iconography can be witnessed in different forms such as human, animal, and composite figurines, seals, pottery, and so forth. Archaeologists recovered a number of figurines made of stone and terracotta from Mohenjodaro. All of them were found broken in "secondary locations", of which the majority of terracotta figurines were recovered not in isolated contexts but together with other figurines from habitation areas of the settlements. According to the author of this article, their function was connected with the private practices of the city's people. This reading has a detailed discussion on terracotta figurines: craft tradition and ideology in the Indus culture.

f) Baloch, N. A. (2017). Non-Aryan Culture of Indus Valley, the Mohen Jo Daro. Sindh Antiquities, 1(1), 3-16.

It seems non-academic that the text of this article does not match its title. What it offers is not relevant to the topic; in fact, not a single paragraph is written on the theme. It is more about the political history of Sindh. Moreover, the text is full of spelling mistakes. One can notice mistakes in each line. It is very difficult to recognize whether the article was written by N.A. Baloch or not. If it was, it seems to have been republished or published with an inappropriate 
or irrelevant title in Sindh Antiquities. It reveals, on the one hand, a sort of carelessness on the part of the publisher with the paper and the scholarship of the author on the other hand.

g) Bhatti, G. R., \& Rajput, M. T. (1997). A Floristic Survey of Mohenjo Daro. Ancient Sindh, 4, 91-97. DASALU.

The survey carried out between 1988 to 1990 reported 46 species of plants belonging to 21 families including shrubs, herbs, and few trees from the Mohenjodaro area. This is the foremost botanical study of the locality. It is very important to establish a laboratory at Mohenjodaro like the one established at Harappa by Americans where extant floral species, as well as faunal skeletons, should be saved for bio-archaeological studies. The authors of this report are botanists from Shah Abdul Latif University, Khairpur and the University of Sindh, Jamshoro.

h) Blake, M. L. (1996). Management Practices and Legislation at a World Heritage Site: A case study of Mohenjodaro, Pakistan. Lahore Museum Bulletin, IX(1), 145-163. AHDL.

Authorities seem concerned about the conservation and preservation of the monumental structures at Mohenjodaro. The rising water table, salinity, moisture, and westward shift in the River Indus are great threats to the site's exposed as well as covered structures, which are under severe conditions. In this regard, measures for its protection were taken by DOAM with the collaboration of the United Nations Educational, Scientific, and Cultural Organization (UNESCO). All these conservational, promotional, and management-related activities started in the early years of the 1960s. In this paper, the author has examined the previous conservation and tourism-management-related works carried out at Mohenjodaro by DOAM and UNESCO "within the framework of Pakistan's legislation and several international charters" (p. 145). The author has emphasized on the preservation and promotion of the site. This is a very important article, especially for students and archaeologists interested in Cultural Resource Management (CRM) or Public Archaeology in Pakistan.

i) Bokhari, H. A. S. (1998). The Sindhu's Saga. The Archaeological Review, 6-8, 221253. SEASL.

This article is on the features of the Indus Civilization, for instance, as outlined by the author, its indigenous and independent origin, autarky, urban centers and entrepots, extent and limits of the civilization, the multiplicity of the site, powerful and patriotic central authority, cosmopolitanism, exemplary town planning, class system, commercial concern, utilitarianism and simplicity, hydraulic cognition, population, contribution, comprehensives, cultural continuity, and language. This is a descriptive paper in which the author has called Mohenjodaro the metropolis of the Indus Civilization.

j) Bukhari, H. A. S. (1995). Mohenjodaro or Moenjodaro. The Archaeological Review, 4(I-II), 238-255. SEASL.

This study has a detailed discussion on the nomenclature of Mohenjodaro. The author has made an account of the names assigned to Mohenjodaro and has argued in the favor of earlier terms or spelling for Mohenjodaro. It is a well-written paper on the subject. The author of this paper is an archaeologist. 
k) Bukhari, H. A. S. (2001). A Needle of Gold from Mohen-Jo-Daro. The Archaeological Review, 8-10, 229-239. SEASL.

In this article, the author has examined one of the antiquities recovered in the initial excavations but never mentioned either by Marshall or Mackay in their comprehensive accounts of excavation i.e., Mohenjo-daro and the Indus Civilization and Further Excavation at Mohenjodaro. This article is about a gold needle that belongs to Mohenjodaro. This article has the description, measurements, and photographs of the gold needle and offers discussion on its functions and use by looking at the ethnographic data from Sindh. Above all, this study discovers lost antiquity which makes this research an important contribution to the Mohenjodaro studies.

1) Excavation at Mohenjo-Daro. (1964). Pakistan Archaeology, 1, 38-39. AHDL.

After 1947, the first excavation at Mohenjodaro was conducted in 1950 by Sir Mortimer Wheeler with the collaboration of DOAM. This report informs that the excavation was carried out to re-examine the city plan of the site, to bring out some facts about its origin and early growth, and to reach the lowest levels of the site. As the final report of excavation had never been published by Wheeler, this report is the only preliminary publication on 1950 excavations. However, the pottery from the 1950's excavation at "Citadel Mound" was published by Leslie Alcock who was the Field Assistant to Mortimer Wheeler at the Mohenjodaro excavation (see Dales \& Kenoyer, 1986, p. 493-502).

m) Excavation at Mohenjodaro. (1968). Pakistan Archaeology, 5, 56-62. CAL.

This report informs about the excavation at Mohenjodaro conducted by George F. Dales in 1964-5. He excavated there for one season at an area, which was then named after him as GFD Area, on the western part of HR Area. It was published as a preliminary report of Dales' excavation by DOAM.

n) Hamidi, T. H. (1976). New Research on Moenjodaro. Sindh Quarterly, II(1), 53-57. RLS.

This paper is a kind of essay on the Indus Civilization and Mohenjodaro. An intriguing aspect of this work is that it mentions that the sculpture of King-Priest is of Mesopotamian nature and relates it with Prophet Abraham and his father, who was a sculptor.

o) Hassan, M. (1975). Trifolium Design as the Insignia of Trismegistus, in Egypt, Mesopotamia and at Mohenjodaro. Sindh Quarterly, I(1), 27-34. RLS.

The author argues that trefoil symbol represents the "three fused solar discs", the sign of Trismegistus or "Thrice Greatest", which has been confirmed by the comparative mythology, originated in Mesopotamia and from there it travelled into Egypt and the Indus Valley. For the evidence from the Indus Valley, the author interprets the sculpture of the King-Priest of Mohenjodaro and the female terracotta figurines (Indus goddesses) wearing three sunflowers type crown on the head. The statue of King-Priest has a solar disc type headband and an armlet of similar shape and has trefoil designs on his cloak. Whereas Indus goddesses' crown has three sunflower designs. The author also states that the people of Mohenjodaro carried trefoil design amulets. The author traces common religious symbols in ancient civilizations. 
p) Hassan, S. K. (1990). An Indus Seal, Depicting an Anthropomorphic Scene. Journal of Asian Civilizations, XIII(2), 77-93. AHDL.

According to the author of this paper, the Indus seals are of two types: square seals and rectangular seals. The motifs and inscriptions are depicted on both kinds. Generally, it is accepted that the square seals were used for stamping purposes and rectangular ones were used as amulets and identity cards. Scholars have given special considerations to the Indus iconography and script. They have given different explanations of art, but the script remained enigmatic as no scholar until now has been able to decipher it. However, the Mohenjodaro seal, one that is discussed in this article, is very famous among Indus scholars who have different perceptions about it (e.g., Maula, 1984; Jairazbhoy, 1990). This study presents the views of different scholars on Seal Number DK2430 ${ }^{3}$ from Mohenjodaro that depicts an anthropomorphic scene, according to the author. Although, he is not sure about what is portrayed on the seal and argues that it would be possible to understand what is depicted on it only when the Indus script is deciphered.

q) Hussain, M. (1989). Salvage Excavation at Moenjodaro. Journal of the Pakistan Historical Society, XXVII(1), 89-98. BHL.

In 1987, while constructing the Larkana Sehwan Bund structural remains were exposed at the level of $145.5 \mathrm{ft}$. at spur number 3. Chert blades, plain and painted pot shreds, miniature pottery, and seals were also identified. To recover the material culture, a salvage excavation was carried out by DOAM at spur number 3, which is 2.5 kilometres away from the Citadel Area of Mohenjodaro. It revealed that all the structural remains and other antiquity belong to the heydays of the city. This report has the detail of that excavation including photographs of the remains. The report provides new information about the city's extension, artifacts, and structures. It is a very valuable contribution to Mohenjodaro studies. The author of this paper was an assistant curator at the National Museum of Pakistan, Karachi.

r) Hyder, A., \& Sangah, N. A. (2018). Unrivalled Mohenjo-Daro Saga. Sindh Antiquities, $1(3), 86-87$.

This is a short essay on Mohenjodaro. Some of the obsolete terminologies and discarded theories have been referred to by the authors such as the Aryan Invasion Theory. This paper is reproduced from already published works on Mohenjodaro.

s) Jairazbhoy, R. A. (1990). The First Goddess of the Indo-Pakistan Subcontinent. Sindhological Studies, 5-25. AHDL.

The religion of the Indus people has been an important subject in Indus studies. This paper mentions that the Mohenjodaro steatite seal, which is Seal A in Mackay's report, ${ }^{4}$ depict 'tree goddess'. In this paper, the author, who does not believe in the religious nature of the Indus figurines, presents the idea of The First Goddess of Indo-Pakistan Subcontinent. In interpretations, the author has found its parallels and combined them with archaeological data. This is a very detailed paper on the Indus religion.

t) Jan, M. Q. (2001). Aryan Destruction of Indus Valley Civilization - Myth and Reality. Journal of the Pakistan Historical Society, XLIX(2), 31-35. AHDL. 
Scholars have different opinions on the decline of the Indus Civilization. Several theories have been put forward, open to debate. Amongst, the Aryan Invasion Theory, which was proposed by Sir Mortimer Wheeler and then advocated by S. Piggott, has been questioned in this study. The author is of the view that nothing has been unearthed so far from the Indus sites which confirms the Aryan's invasion hypothesis. He refutes the Aryan's invasion theory, although it was already challenged and invalidated by G.F. Dales in his famous article entitled The Mythical Massacre at Mohenjo-Daro. ${ }^{5}$ Therefore, I dare to say that Jan's article is not a new contribution to the field, but reproduction.

u) Jansen, M. (2018). Condition Report of Mohenjo-Daro-1987. Sindh Antiquities, 1(3), 48-55.

This report was prepared on the structural remains of Mohenjodaro by the author and his team. The work was carried out after the decision taken in the seventh meeting of the UNESCO Executive Board for the safeguarding of Mohenjodaro in July 1988 in Paris. This report mentions that the physical preservation and conservation of the site should be based on the study of the historical data, especially old photographs of the structures. The author is a wellknown scholar of Mohenjodaro studies.

v) Khan, M. S. (1992). Moenjodaro - problems and solutions. The Archaeological Review, 1(I), 91-97. AHDL.

This paper provides an outline of the issues causing damage to the monumental structures at the site as identified in the Master Plan. With that, to overcome the situation, this paper also presents a list of solutions. Moreover, the author has discussed the positive and negative effects of previous activities.

w) Khan, M. S. (1993). Salt Extractions from Moenjodaro Burnt Bricks Structures by Poulticing Method. The Archaeological Review, 2(I-II), 167-175. SEASL.

The fast decay of burnt brick structures at Mohenjodaro is due to the evaporation and soluble salts. Bricks need immediate treatment and removal of soluble salts. The author, when given the charge of Water and Soil Investigation Laboratory (WASIL) Mohenjodaro, applied a new Mud Poulticing Method on burnt brick structures. The first experiment of the Mud Poulticing Method was made on the walls in the DK-G Area. This article has a list of results obtained in experimentation. The author has argued that four applications of the Mud Poulticing Method on the bricks above the damp-proof course (DPC) can minimize extraction of salts and continuous poulticing is required for the bricks below DPC. It shows that the poulticing not only desalinizes but also consolidates the bricks.

x) Khan, M. S. (2001). Salinity a threat to Moenjodaro: Control Measures based on scientific study. Lahore Museum Bulletin, XIV(1), 65-81. LML.

In this paper, the author has suggested measures for the conservation of Mohenjodaro. For example, mud poulticing for desalinization of bricks and mud slurry for fragile bricks. Along with this, he has discussed the causes of deterioration i.e., water, climate conditions, one-sided excavated walls, undecorated visitors, previous conservation treatments, subsoil water table, and soil and water salts. 
y) Khan, M. S. (2006). Monsoon Preparation Work at DK-G Area Moenjodaro during 2005. Ancient Pakistan, XVII, 91-100. AHDSL.

This progress report has recommendations to save the monumental structures in the DK-G Area from the monsoon. The photographs of the structures, taken before and after treatment, show the state of the Area. This paper was presented on the occasion of the First International Symposium on Latest Discoveries in the Cultural Heritage of Ancient Gandhara and Other Parts of Pakistan held in Swat.

z) Khan, M. S. (2009). Moenjodaro: A World Heritage Site at risk. Ancient Pakistan, XX, 217-246. AHDSL.

This paper highlights the issues of conservation and the threats to the site. It also provides information about the schemes/plans made by the Government of Pakistan and UNESCO to save the site from decay. The paper was presented at Second International Symposium on Latest Discoveries in the Cultural Heritage of Ancient Gandhara and Other Parts of Pakistan 2008, organized by the Department of Archaeology, University of Peshawar.

aa) Khan, M. S., \& Khan, M.I. (2006). Monsoon Preparation Work at Moneer Area Mohenjodaro, 2005. Journal of Asian Civilizations, XXIX(2), 1-13. AHDL.

This paper outlines the measures taken during the monsoon preparation work at Moneer Area in 2005, with a brief mention of 1987 conservational activities. Primarily, this is a report of the work done in 2005 at Moneer Area. This report has recommendations for short and mediumterm actions to prevent further decay of structures during monsoon season. It also has location maps and photographs of the conserved structures. The author has stated that all the work was practiced professionally according to the principles and charters of UNESCO.

bb) Khan, M. S., \& Khan, M.I. (2011). Monsoon Preparation Work at Moneer Area Moenjodaro, 2005. Lahore Museum Bulletin, XX-XII(1-2), 127-130. LML.

This report was first published in the Journal of Asian Civilization in 2006 (see preceding entry).

cc) Khan, A. N., \& Ochani, M. L. S. (1990). Conservation of Moenjodaro Structural Remains - A progress report: 1980-89. Pakistan Archaeology, 25, 283-302. DOAM.

It is a progress report of conservation work done at Mohenjodaro which was funded by the Authority for the Preservation of Moenjodaro in the years 1979-80 to 1989-90. It mentions that a total of 1700,000 Pakistani rupees were allocated for the project. This paper also provides the details of conservation, consolidation, and installation work done at S.D. Area and mention that between 1983-84 and 1984-85 salty mud was trenched out to a depth of 1 foot and replaced with a 6-inch layer of river sand on top of a sweet mud layer of 6 inches. From the northern side of the V.S. Area, dumps of the stack were removed and thrown away towards the bund (p. 300). During the same years underpinning was done at the H.R. Area and the D.K. Area to strengthen falling walls. The collapsing walls at the H.R. Area, D.K. Area (G Section), and L. Area were supported by the Mud Pushtaqs. Moreover, the report also mentions by referring to previous works that the structural remains at Mohenjodaro are threatened by salinity and change in the course of the mighty Indus. ${ }^{6}$ 
On the whole, the deterioration process involves salt action, moisture, rainwater, the rise in groundwater level, and river erosion. The authors also draw on the solutions to such problems given by the experts (both foreign and Pakistani) to overcome the situation. The report has referred to several works, without acknowledgment and bibliography. It also lacks in-text citation. Both the writers of the report were employees of DOAM. Ahmad Nabi Khan was an archaeologist and Mohan Lal S. Ochani is an architectural conservationist. Mohan has worked with several foreign missions at Mohenjodaro.

dd) Kiani, K. (1976). The Moenjodaro Opuscule (dedicated to the memory of Justice Feroze Nana Ghulam Ally) ${ }^{7}$. Sindh Quarterly, IV(4), 25. RLS.

This is a short poem with an epilogue. The poem contains 15 couplets: twelve in the first part and three in the epilogue. In the first part, the writer has depicted the glorious life in Mohenjodaro and the relationship it enjoyed with Mesopotamia. The author has wonderfully used the artifacts from the city's remains and the names of Mesopotamian states as metaphors. This trend of publishing poems in literary journals is not unlikely, as Sindh Quarterly was a literary journal. For example, the poem "The First Cloud", which was translated from Bengali into English by Subhrajyoti Bhattacharya, was published on Mohenjodaro in a literary journal called Indian Literature. ${ }^{8}$

ee) Mahdihassan, S. (1984). Fertility Symbolism on Taxila Potteries traceable upto Moenjo-Daro. Sindhological Studies, Summer, 12-18. RLS.

This paper is based on two pottery objects discovered by A. Ghosh in Taxila. The author has proposed that the symbols bedecked on the pottery found in Taxila have been also witnessed on the Indus Mother Goddesses. In this study, the signs depicted on pottery are interpreted as fertility symbols.

ff) Majid, H., \& Ishaq, M. (1993). An evidence of Seal Making: A new collection of Indus Seals in N.M.P. Karachi. The Archaeological Review, 2(I-II), 280-289. SEASL.

The Acquisition Committee of the National Museum of Pakistan acquired some Indus seals in 1985. Amongst, 10 seals are part of this paper. Of which, seal number 9 and 10 of this paper were found in the "Salvage Excavation in March 1987" at Mohenjodaro. Both are made of white steatite depicting unicorns and pictographs. This paper has the detail of the 10 seals acquired by the National Museum of Pakistan.

gg) Maula, E. (1984). The Calendar Stones of Moenjo-Daro. Sindhological Studies, Summer, 19-32. RLS.

The author has interpreted the stone objects i.e., ring-stones or yoni stones, linga stones, and cones, using higher mathematics and astronomy. It has been proposed by the author that these stone objects found from Harappa and Mohenjodaro are astronomical instruments that are closely associated with the antiquity of the Indus Civilization cosmology. For the "great ringstones", "nine of them are at Moenjodaro Museum, three at Prince Wales Museum in Bombay, and one at the Madras Museum" (p. 22). They are called "Calendar Stones" of Mohenjodaro. Apart from this, the author has assigned astronomical meanings to Seal Number DK 2030. But his work is not clear, as criticized by R. A. Jairazbhoy. ${ }^{9}$ 
hh) Meadow, R. H. (1993). The Past, Present, and Future of Bio-Archaeological Studies in Pakistan with specific reference to Moenjodaro and the Indus Civilization. Pakistan Archaeology, 28, 183-215. DOAM.

In this paper, the author has discussed the theory and the history of bio-archaeological research. With that, he has discussed the growth and development of bioarchaeology in Pakistan. This paper also provides an overview of some works on the faunal and floral remains from prehistoric sites (Indus Valley). While in the discussion on Physical Anthropology, Paleoethnobotany, and Zoo-Archaeology, the author has highlighted the "key findings and the unresolved question". Along with this, he has suggested the possibility for future bioarchaeological studies of Mohenjodaro. As the faunal and botanical remains from Mohenjodaro are too scarce, Meadow stresses on the recovery of such material from the rescue excavations and operations for further research. Richard H. Meadow is a well-known scholar of the Indus Civilization. This work shows his scholarship in the field.

ii) Mohenjodaro. (1971). Sind Annual, 309-311. CLQAU.

One part of this report is on Mohenjodaro. It informs about the conservation and preservation work and activities of UNESCO and other national and international organizations at the site.

jj) Mughal, M. R. (1994). Ancient cities of the Indus. Lahore Museum Bulletin, VII(1-2), 53-57. AHDL.

This is a well-written research paper on the ancient cities of the Indus Civilization. In this study, the author has shown Mohenjodaro as the largest among all the Indus cities. The author of this paper is a well-known archaeologist of Pakistan and a distinguished scholar of the Indus Civilization.

kk) Mughal, M. R. (1990). The Harappan "Twin Capitals" and reality. Journal of Asian Civilizations, XIII(1), 155-162. AHDL.

It was believed that Mohenjodaro and Harappa were the twin-capitals of the Indus Civilization. But, with the discovery of other Indus cities, particularly Ganweriwala in the Bahawalpur District, the theory of twin capitals is no more accepted. Mughal's major survey in the Cholistan region is of great importance in this regard.

11) Nazeer, A. C., \& Bhatti, H.N. (2006). Mohenjodaro Ciphers: EA and Math Model. Journal of Asian Civilizations, XXIX(1), 1-30. AHDL.

Indus script remains a mystery. Efforts have been made to decipher the script but in vain. Scholars thought that the signs of the Indus script are of spoken language. On the contrary, the authors of this paper argue that the symbols written on the seals, amulets, and tablets were the secret codes used by the priests, nobles, and elites. A case of Mohenjodaro ciphers has been taken into account with the help of ethnoarchaeology and cryptology (in this study termed as EA and Math Model).

mm) Phulpoto, A. N. (1987). Symbols on Pre-Aryan Seals of Indus Valley. Winter, 5-15. RLS. 
In this research paper, the author has discussed the symbols on the Indus seals, their evolution, and their influence on later Indian art. $\mathrm{He}$ is of the view that the seals from the Indus Civilization give a sense of early Indian art and culture and were the work of the local artists. The author of this paper was a faculty member at the Department of Fine Arts, University of Sindh, Jamshoro, Pakistan.

nn) Rasool, N. (2017). Mohenjodaro Site and Museum. Sindh Antiquities, 1(1), 96-98.

This is a descriptive essay on the museum and monumental structures at Mohenjodaro. This cannot be deemed as the (original) research work because of the lack of proper referencing. The text of the article shows that the author has reproduced it from other works without mentioning/acknowledging their work. I do not think that this is something that was primarily written for a research journal. This paper should have been published in popular print media: newspapers and magazines. The author of this paper was the former Director-General of DOAM, Islamabad, Pakistan.

oo) Saleem, M. (1991). Missing and New Studies on Moenjodaro. Journal of the Pakistan Historical Society, XXXIX(4), 373-402. BHL.

In 1988, the University of Karachi, Pakistan conducted the Ethnographic Studies Program (ESP). One purpose of that project was to collect the archaeological reports of one month, September-October 1972, of the survey conducted in the southern Sindh by the DOAM, Pakistan. The author of this paper was assigned the job of collecting the reports. In this paper, the author has emphasized particularly on the missing reports of previous works at Mohenjodaro. On the other hand, he has discussed the works of the Mohenjodaro Research Project undertaken by RWTH and IsMEO.

This paper mentions that, according to G. F. Dales, the reports of 1932-1934 excavations by Q. M. Moneer and K. N. Puri are not available at the site, except for some seals, a map of the area that was published by Wheeler in 1950, and other antiquity which were noticed by Iravatham Mahadevan in New Delhi, India. About the IsMEO-RWTH project at Mohenjodaro, as the new studies, the author has discussed the Surface Evaluation Program (SEP) and Geophysical Prospecting along with some aspects of modern technological concepts. His work can be better termed as the textual survey of the archaeological reports. The author was a faculty member of Department of General History, University of Karachi, Sindh, Pakistan.

pp) Sangah, N. A. (2018). Condition Report of Moehnjo-Daro-2017. Sindh Antiquities, $1(3), 9-18$.

This paper provides an information related to the conservation work at the site and also mentions that the structures are protected from salt attacks and monsoon threats. Whereas, in this report, it is proposed by the author that drainage problems can be solved if the slope is created on the ground level. The photographs of the decaying structures are also given at the end of the paper. The author of this report is an employee of the Archaeology Department, Government of Sindh.

qq) Shaikh, K. H. (1991). Ethnoarchaeology as an aid to interpret Indus Civilization. Pakistan Archaeology, 26, 108-114. DOAM. 
Some of the traditions of local people can be linked to the Indus Civilization. In this article, K. $\mathrm{H}$. Shaikh has shown the association between the Indus Civilization and the Mohanas fishermen community living in Sindh - in the framework of ethnoarchaeology by looking at the analogies between past material and the present traditions. Through the study of the material culture recovered from the Mohenjodaro e.g., the seals depicting boats and the symmetrical depiction of two birds on the boat, the author opined that the Mohanas have close links with the Indus Civilization.

This paper also mentions an interesting tradition that in the rainy season the Mohanas organized a festival on the east bank of the Indus River opposite to the ruins of the Mohenjodaro that might be the continuity of past festivals. He further suggests the ethnological studies on the designs on the "wooden houseboats may reveal other resemblance with the sculptural art" of the Indus Civilization. However, the philological studies on the language of Mohanas (a dialect of Sindhi having some "peculiar words") can be helpful in the decipherment of the Indus script. Shaikh has formulated a theoretical framework for further studies on this. This study can be of high importance to understand the antiquity of the riverine community of the Lower Indus Valley as well as the Mohenjodaro's past. The author of this article was the Director of DOAM, Islamabad, Pakistan.

rr) Shaikh, N. (1996). Mohenjo-Jo-Daro: A challenge in conservation. Ancient Sindh, 3, 49-65. DASALU.

In this paper, Nilofer Shaikh has critically seen the operations and methods of the preservation and conservation of monumental structures at Mohenjodaro conducted by DOAM, UNESCO, and other organizations. The author has pointed out both positive and negative results of conservational activities. She argues that all the experiments were done on the original structures that should have been done first in "simulated condition" to find out whether the method is effective or reliable and can do no harm to remains before applying them to the original structures at the site and have proved to be less favorable and more destructive. She underlines the involvement of archaeologists in such activities. This article is very important because it highlights the merits and demerits of conservational works. Nilofer Shaikh is a wellknown archaeologist of Pakistan.

ss) Shaikh, N. (1990). Brick Industry of Mohenjodaro. Lahore Museum Bulletin, III(2), 1923. LML.

This paper is written in the framework of ethnoarchaeology. The author argues that the brick industry of the Mohenjodaro was an indigenous development. She has used the analogy to verify her hypothesis. Moreover, the contemporary method (process) of brick making in modern Sindh is also described in this paper.

tt) Shaikh, N., \& Shar, G.M. (1988). An Industrial Centre in Mohenjo-Daro Lower City. Journal of Asian Civilizations, XI(2), 127-140. AHDL.

Earlier archaeologists thought that most of the buildings were permanent residences in the DK$\mathrm{G}$ Area in the Lower City. One building was identified as a palace by Mackay. Later on, studies were conducted to find out whether the area was used by the elites in past. These research were based on architectural and artefactual analysis. One such example is the joint study of N. Shaikh and G.M. Shar, both are retired archaeology professors, who identified that the palace in the 
DK-G Area's Southern Section was an industrial centre. Along with this, some other structures in the same area were also identified as workshops where the presence of kiln, drills and silver casting, and minor antiquity supports the idea of authors that some kind of craft activities were carried out in these places.

uu) Shaikh, N. (1987). Mohenjodaro's Trade Relations with the West. Sindh Quarterly, XV(2), 33-43. RLS.

Based on the archaeological record, this paper is written on the trade relation of Mohenjodaro with Mesopotamia, Iran, Turkmenistan, Afghanistan, and the Persian Gulf in the second half of the third millennium BCE. Moreover, it has the details of trade routes, commodities, and raw material, which had been traded, and the presence of Indus seals, sealings, and weights in the West Asian regions. This paper shows that Mohenjodaro had trade relations with far-flung areas. The author of this paper did her Ph.D. on the trade of the Mohenjodaro peoples. This paper might have been produced from her Ph.D. dissertation.

Various issues were identified in the Master Plan of 1972 for the preservation of Mohenjodaro. This work is a kind of report which focuses only on the conservation issues and reports the progress of work. Although this work is based on the Master Plan of 1972 which was prepared by UNESCO and the Pakistani team, there is no reference of it in the text or in the bibliography, which is missing. The author of the paper was former Coordinator, UNESCO-UNDP, and Director General of Moenjodaro Preservation Authority.

ww) Shar, M. M., \& Kubar, I. A. (2014). The use of Beads in Ornaments by the Peoples of Indus Valley Civilization: Bead manufacturing techniques, materials and their origin. The Grassroots, 48(II), 213-226. CLUS.

Indus bead technology is one of the important aspects of Indus studies. Archaeologists have given special consideration to it. The beads of the Indus Civilization have been studied in different frameworks. On beads, the work of Jonathon Mark Kenoyer is of immense value. He has studied beads from an anthropological perspective with the help of experimental archaeology and ethnoarchaeology. Beads are very important to make a sense of the Indus craft production, trade, and economy. However, a comparison of this article with others reflects its weaknesses, both in theoretical and methodological terms. Very poor in style, this work cannot enhance our knowledge about the Indus beads. M.M. Shar teaches archaeology at the University of Sindh, Jamshoro.

xx) Sharif, M. (1990). Some New Seals from Mohenjo-daro and the evidence of Seal Making. Lahore Museum Bulletin, III(1), 15-18. AHDL.

Salvage excavation in the north-eastern limits of the city mound rescued some seals and sealing, as well as other antiquity. After careful investigation of the material, it was proposed that the salvaged area might be the seal-making workshop. This paper has a description of seals along with illustrations given at the end.

yy) Siddiqui, S. (2017). Terra Cotta Figurines at Mohenjo-Daro. Sindh Antiquities, 1(1), 39-47. 
From the Mohenjodaro terracotta figurines were recovered in abundance. They were examined and given different meanings by the researchers. Some scholars think that figurines have religious characteristics while others believe in their plaything functions and so on. Sir John Marshall, M. S. Vats, and E. J. H. Mackay thought that terracotta objects were the children's toys. The author of this article also believes that the animals and the human terracotta figurines were toys.

zz) Talpur, P. (2017). The Crown of Moen Jo Daro: Long forgotten Stupa and Holy Places of Buddhism in Sindh Pakistan. Sindh Antiquities, 1(2), 28-32.

This paper is on the current state of research on the Buddhist heritage of Sindh, particularly the Stupa at Mohenjodaro. The author writes about the discovery and history of the construction of the Mohenjodaro Stupa.

aaa) Qasim, Q. A. (2018). Town Planning and Architecture of Mohenjodaro. Sindh Antiquities, 1(3), 19-25.

Along with a short description of some monumental structures, this paper includes minor definitions of the architectonics of Mohenjodaro. Nothing new has been added to our knowledge about Mohenjodaro. All it includes is reproduced from the previous works of different scholars. The author of this paper is a retired officer of DOAM.

\section{Approaches in Mohenjodaro archaeology}

\subsection{Excavation}

Three preliminary excavation reports which include Wheeler's (1950), Dales' (1964), and salvage excavation of 1987 conducted by DOAM are part of Mohenjodaro studies. Wheeler at Stupa Mound and Dales on the western side of HR Area dug deep trenches - their method of excavation was vertical. Their primary objective was to reach the lowest level, to document the earliest occupation, and to know about the origin and growth of the city. We know that Wheeler's one objective or one can say his responsibility because he was the Archaeological Advisor to Pakistani Government, was to teach and train students in the 'Wheeler's excavation method' (Khan \& Shaheen, 2018, p. 183). However, Dales' other objective was 'to re-examine the existing concepts about the decline and disappearance of Indus Civilization' (Mohenjodaro, 1964-5, n.a.). Lastly, the salvage excavation of 1987 was conducted by DOAM to rescue and recover the archaeological record which was exposed while constructing Larkana Sehwan Bund at spur 3 at a distance of 2.5 kilometres from Stupa Mound, and with that discovery, it was confirmed that the city is further extended towards the riverside and some part of the city is buried beneath the silt of Indus River (Hussain, 1989).

\subsection{Survey}

Pakistani scientists (physicists, chemists, biologists, and the rest) have rarely participated in archaeological research. It shows that, in Pakistan, archaeology is not aided by other sciences. But scientists' little involvement in archaeology had been very helpful for archaeologists in the past. In 1988-1990, a botanical survey of the Mohenjodaro area was carried out by two scientists from Shah Abdul Latif University, Khairpur and the University of Sindh. The study (Bhatti \& Rajput, 1997) documented 46 species of plants belonging to 21 (twenty-one) 
families. Their survey is very valuable because its results have revealed that there are shrubs and plants grown at the site that are causing harm to the exposed as well as unexposed structures. It is the only survey of its kind on Mohenjodaro, or any other archaeological site in Pakistan, ever done by Pakistani science institutions.

\subsection{Conservation and Culture Resource Management}

The practices of conserving, restoring, preserving, promoting, managing, and popularizing heritage are part of Cultural Resource Management (CRM). CRM relates to what is called public archaeology because it has a direct relationship with the public. The conservation, preservation, and management of sites particularly Mohenjodaro has been a big challenge for government and cultural organizations. Because Mohenjodaro, one of the frequently visited archaeological sites in Pakistan, has always been under threat of fast decay - structures there have been deteriorating day by day from the time it was exposed due to bad environment and human agency. Both national and international organizations have been active in the conservation and preservation of structures as is obvious from the number of publications on the issue (UNESCO, 1964; Shaikh, 1996).

Most of the papers in the Pakistani research journals are reports of conservation works at the site (e.g., Jansen, 2018; Khan, 1992, 1993, 2001, 2006, 2009; Khan \& Khan, 2006, 2011; Khan \& Ochani, 1990; and Sangah, 2018). Whereas one paper is on preservation (Shamsi, 2017); and Blake (1996) has discussed legislation and management of the site. However, Shaikh (1996) has discussed the merits and demerits of conservation activities at the site. She emphasized the involvement of archaeologists in archaeological conservation and pointed out that the experiments were done on the original structures. She believes that the experiment should have been done first in the simulated condition to know the pros and cons of methods. Moreover, there are few other papers on Mohenjodaro's site and museum written in the framework of CRM that can be better considered as the popular archaeology articles ${ }^{10}$ that should have been published for the general public in the newspapers and magazines but research journals (e.g., Rasool, 2017; Hyder \& Sangah, 2018; Talpur, 2017; and Qasim, 2018). Apart from these, one poem (Kiyani, 1976) and a book review (Ahmad, 1994) are also part of Mohenjodaro studies.

\subsection{Ethnoarchaeology and bioarchaeology}

Few studies have been also carried out in the frameworks of ethnoarchaeology and bioarchaeology. Both fields of archaeology have western scientific archaeology background. Richard Meadow in his paper on the current state of bio-archaeological research in Pakistan has underlined the importance of future bio-archaeological research on Mohenjodaro (Meadow, 1993). However, ethnoarchaeological studies have been conducted to make sense of ancient brick technology at Mohenjodaro (Shaikh, 1990), and to trace the founders of the city by looking into extant traditions and material of Mohana, who are thought to be the oldest living community in Indus River Valley (Hassan, 1991).

\subsection{History of archaeology}

In 1972, DOAM conducted a survey in southern Sindh. One objective of Karachi university's Ethnographic Studies Program (SEP) was to collect the reports of one month of that archaeological survey by DOAM. This task was assigned to M. Saleem, a former faculty 
member at the University of Karachi. During the course of the research, he found that the reports of excavation conducted after 1931 are missing. In his paper, Saleem (1991) write about the missing reports of 1932-1934 excavations by Q. M. Moneer and K.N. Puri and highlights the activities of the IsMEO-RWTH project.

\subsection{Nomenclature}

Mohenjodaro's nomenclature is also part of Mohenjodaro studies. Bukhari (1995) takes on the nomenclature of Mohenjodaro and argues that the site should be called 'Mohenjo-daro' because the site was first time written like this, and this spelling match with the local name. Although, the ancient name of the site remains a mystery to be solved. If we look into the history of the archaeology of Mohenjodaro, we will come across the fact that how and why the site had been called with different names in different social and political contexts, mostly 'as the cursed city' or 'the place of the dead' and associated with a despot Hindu king of the historic period. But no one knows the ancient name of the site because the language of Mohenjodaro or the Indus Civilization is not known. It would be only possible to know the ancient name of the city when the Indus script is deciphered.

\subsection{Architectural and artefactual studies}

Architectural and artefactual research is also part of Mohenjodaro studies. Shaikh and Shar (1988) re-examined the structures at the southern section of the DK-G Area and artifacts found from there. They argue that the place was an industry as evident from the presence of kiln, drills and silver casting, and minor objects. They challenged Mackay's idea of 'palace', which they have identified as workshops. Whereas, based on the material found in a salvage excavation in the late 1980s, Sharif (1990) writes about evidence of seal making (workshop) in the eastern side of the city. His study can be helpful to understand the Mohenjodaro craft technology. Moreover, the site distribution pattern and town planning of Mohenjodaro are also well-studied by archaeologists. Few of the papers have been published on the town planning and architecture of Mohenjodaro in Pakistani journals. But there is still much more to dig out - particularly its political status in the past. Published on this topic, the papers of Qasim (2018), Hyder \& Sangah (2018), and Rasool (2017) are reproduced from previously published works and do not make a valuable addition to the Mohenjodaro studies. In the same field, Rafique Mughal also published two articles in which he has challenged the theory of "Twin Capitals" of the Indus Civilization (Mughal, 1990) and has shown Mohenjodaro as the largest among Indus cities (Mughal, 1995).

Mohenjodaro yielded abundant material, including rare artifacts which have been only found from there, more than any other site of the Indus Civilization. Some of its material was reexamined and published. There are few papers on its material objects published in Pakistani journals. Scholars have re-examined the material culture and presented new ideas about the use of artifacts and identified structures based on architectural evidence. For example, Allchin (1991) identifies the figurine of ram which was brought to Europe during Colonial India. He argued that the figurine belongs to Mohenjodaro. Other important studies are on the terracotta figurines (Ardeleanu-Jansen, 1988; Siddiqui, 2017; Hamidi, 1976). Moreover, Indus beadmaking technique is studied by Shar and Kubar (2014), but their study is not well organized as it lacks methodology. However, Bokhari (1998) mentions the gold needle, which was not documented and studied by earlier archaeologists who worked at the site. Another study (Ahmad, 1991) gives the details of the restoration of the Bronze Cooking Pot which is at the 
exhibition in Lahore Museum, and Majid (1993) documented the Indus or Mohenjodaro seals at National Museum Karachi. Thus, these material culture studies give a sense of the past of the Indus Civilization in general and Mohenjodaro in particular.

\subsection{Language}

The excavations at the site revealed more than two thousand inscriptions on seals, goldsmith tools, pottery, and other objects. Many scholars have tried to decipher the inscriptions (language) written on these artifacts but failed to do so. There are two papers (Shaikh, 1990; Nazeer \& Bhatti, 2006) on the Indus script published in Pakistani research journals. Shaikh (1990) conducted anthropological research on the Mohana community in Sindh. He argues that the language that Mohana speak has non-Sindhi words which may have some links with the ancient Indus language. He proposed that with the help of ethnoarchaeology it might be possible to decipher the Indus script. Another study (Nazeer \& Bhatti, 2006) shows that the symbols/signs depicted on the various things are not of spoken language but were the secret codes used by the elites and nobles of the cities. This study is not easy to understand because it is based on higher mathematics.

\subsection{Arts and religion}

The sculptures of human beings and animals and iconography on seals and pottery best define the art and religion of Mohenjodaro. The seals and most of the figurines are miniature, small in stature and size. The seals are made of steatite, terracotta, and copper. Mostly the seals are equal in size measuring one inch by one inch and have human, composite animal, and floral and faunal depictions. Indus seals also have inscriptions. Since the inscriptions are not deciphered, the scholars have to rely on iconography to know about the religion of the Indus people (Phulpoto, 1987). The iconography on Indus seals and pottery has been interpreted within a religious framework and art history (Hassan, 1975, 1984; Hassan, 1990; Jairazbhoy, 1990). It is a common perception amongst the scholars of the Indus Civilization studies that the belief of the Indus people is more evident in iconography, cult objects, and architecture it is only in the case of Rakhigarhi where fire altars have been found. But, for the religion of Mohenjodaro best evidence is iconography depicted on seals.

\subsection{Trade}

Both domestic and overseas trade of the Indus Civilization has been a recurring topic in the Indus Civilization studies. Shaikh (1987) wrote about the trade relations of Mohenjodaro with western areas. There is abundant evidence showing the connections between the Indus and its contemporary civilizations. Was really that a trade connection? Scholars now doubt the commercial value of some antiquity. They argue that objects like Harappan cylindrical terracotta beads were given as gifts like we do today. In this regards, anthropological research can make value addition and enhance our knowledge about the issue.

\subsection{Decline}

One can find different theories on the decline of Mohenjodaro (see Lahiri, 2000/2006). Some archaeologists said that the city was destroyed due to frequent floods in the Indus River, others talked about the foreign intruders: Aryans, and there were/are some who in general thought about the natural calamities like earthquakes and drought. Studies on the decline of 
Mohenjodaro published in Pakistani journals are reproduced from earlier works (e.g., Ahmad, 1981; Jan, 2001). For the city's destruction, Ahmad (1981) referred to the floods and Jan (2001) wrote about the 'Aryan's invasion'.

\section{Discussion}

The papers on Mohenjodaro can be classified into different categories according to the nature of the studies. The point that Mohenjodaro studies are highly influenced by the archaeological approaches is demonstrated in this study. The categorization of studies makes this point clear as it shows the theoretical approaches in Mohenjodaro studies, and it also shows that Mohenjodaro archaeology is not limited to archaeological explorations, excavation, and survey but it has a deep theoretical basis and has on it the strong impacts of archaeological philosophical outlooks. With the help of pre-modern and modern archaeologies, the scholars have been able to interpret, give meanings, revise previous knowledge, and draw a new conceptual framework for further research. One can say with certainty, in some cases, that not all the papers are researched and written well, especially reports and an article by N. A. Baloch (2017) in which the authors have reproduced the text. Particularly, in the case of N. A. Baloch's paper the contents do not match with the title of the paper. There is another set of reproduced papers on the Mohenjodaro archaeological complex and the city's layout and architecture (e.g., Rasool, 2017 and Hyder \& Sangah, 2018; Qasim, 2018). Although, published in a peer reviewed research journal, but these articles cannot fit into the definition/category of academic or research article. Neither have they fulfilled the criteria of popular writings due to their publication in academic journals even though this researcher has called them popular archaeology articles.

Mohenjodaro studies are also influenced by the ideas of antiquarianism and culture history such as description and subjective interpretations of material culture and study of Mohenjodaro from the perspective of Old-World Civilizations, and as well as modern archaeology. For example, Ardeleanu-Jansen presents terracotta figurines as cultic objects used by the individual in their houses and Siddiqui viewed them as toys. About the only sculpture of King-Priest, Hamidi's point is weak - he thought that the sculpture is Mesopotamian and has some connection with the father of Prophet Abraham who was a sculptor. King Priest's sculpture has a headband, armlet, and shawl having elaborate trefoil decoration wrapped on the body. Hassan discusses the trefoil symbols on the sculpture of King-Priest and Indus goddesses wearing three sunflowers like crown represent three solar discs, which is a sign of Trismegistus - thrice greatest. However, symbols or "fertility symbols" depicted on the pottery of Taxila have been linked with the Indus Mother goddesses (see Mahdihassan, 1984). Maula sees the ring stones of Mohenjodaro in the framework of astrology. But scholars did not agree with him because of his subjective interpretations (see Jairazbhoy, 1990).

Another study by Jairazbhoy mentions that the tree goddess was the first goddess of the subcontinent, and the people of the Indus Civilization worshiped the tree goddess. Whereas the works of Rafique Mughal, Nilofer Shaikh, Khursheed-ul Hassan Shaikh, F.R. Allchin, Richard Meadow, and M.L. Blake are influenced by the ideas of modern archaeology, for instance, collection of data through excavations and surveys for scientific analyses, ethnoarchaeology, scientific interpretation of cultural material, bio-archaeology, CRM, and so forth. They have provided new information and contributed to the knowledge of the Indus Civilization. Mughal criticizes older scholars, for his arguments are scientific. For instance, it was thought by the earlier archaeologists that Mohenjodaro and Harappa were twin-capitals of the Indus 
Civilization, but based on his archaeological explorations in the Cholistan desert, where he found a city's remains called Ganweriwala, which is of the size of Harappa and Mohenjodaro and is located in the centre of both settlements, Mughal refutes twin-capitals theory (see Mughal, 1990). On the other hand, Nilofer criticized the conservation and preservation work carried out at Mohenjodaro and the techniques applied in it (see Shaikh, 1996) and re-examined structures and material found from a building, previously identified by Mackay as a palace, at DK-G Area and proved that it was an industrial area (see Shaikh and Shar, 1988). Nilofer has also worked on the brick industry of Mohenjodaro in the framework of ethnoarchaeology (see Shaikh, 1990).

On the other hand, Khursheed-ul-Hassan, another scholar working in the same line, has taken insights from anthropology. This is reflected in his studies on the iconography of a Mohenjodaro seal (see Hassan, 1990) and ethnoarchaeology's importance in solving few issues related to inhabitants of Mohenjodaro and their language (see Hassan, 1991). Whereas Allchin (1993) brought to the fore the lost antiquity of Mohenjodaro. His idea was that the sculpture of ram, which he found in the collection of an antiquity dealer of London, belongs to Mohenjodaro. Moreover, Meadow's involvement as a bio-archaeologist in Indus Civilization studies seems to be of great importance. He has emphasized on bio-archaeological research on Mohenjodaro. Keeping in view the scarcity of faunal and botanical evidence for scientific analyses, he suggested the possibility of collecting more data through salvage excavations and other operations. However, Blake discussed legislation and management practice at Mohenjodaro. There are enough laws for the preservation, safeguarding, and management of archaeological or cultural heritage sites in the Pakistani constitution, besides various international charters for the conservation and management of sites.

\section{Conclusion}

This research shows that a total of 53 papers, which include reports of archaeological excavations, surveys, and conservation and preservation of monuments, research articles, a poem, and a book review, on the Mohenjodaro are published in journals dedicated to archaeology, history, culture, and literature. These papers are written on various aspects of Mohenjodaro such as its topography, discovery and history of fieldwork, nomenclature, urban planning, site distribution, archaeological record, script, religion, trade relations, decline, and archaeological potential. Thus, it is argued in this study that the papers are written by both archaeologists/professionals and non-archaeologists. The works of professionals are in the form of conservation reports and articles on material culture whereas the poem, apart from other popular writings, is one good example by non-archaeologists. Those papers which lack in-text referencing and bibliography have been referred to as popular writings. It is not discriminating while arguing that the works of foreign scholars are stronger than most of the Pakistani scholars from a theoretical and methodological point of view, because the reproduction of text shows most of the Pakistani scholars' non-academic approach. Certainly, these reproduced works do not make any value addition to the Indus Civilization. Alongside, there are few Pakistani archaeologists like Nilofer Shaikh, Rafique Mughal, and S.K. Hassan, who has produced a valuable work inspired by the ideas (philosophical outlooks or trends) of modern archaeology. 


\section{References}

Bhattacharjee, S. B. \& Bhattacharya, S. (2007). The First Cloud. Indian Literature, 51, 1(237), 48-49. https://www.jstore.org/stable/23347875

Dales, G. F. (1964). The Mythical Massacre at Mohenjo-Daro. Expedition Magazine, Spring, 28-43. http://www.pemm.museum/sites/epedition/

Dales, G. F., \& Kenoyer, J. M. (1996). Excavations at Mohenjodaro, Pakistan. The Pottery. University Museum.

Kenoyer, J. M. (2005). Mohenjodaro: An Ancient Indus Valley Metropolis. https://www.harappa.com/category/essay-name/mohenjo-daro-ancient-indus-valleymetropolis

Khan, R. \& Shaheen, I. (2018). 'The Vulgus is No Bad Judge' - Sir Mortimer Wheeler and the popularization of Indo-Pakistani Archaeology. Journal of the Pakistan Historical Society (Historicus), LXVI(1-2), 175-203.

Lahiri, N. (Ed.). (2000/2006). The decline and fall of the Indus Civilization (4 ${ }^{\text {th }}$ ed.). Permanent Black.

Mackay, E. J. H. (Ed.). (1938/1998). Further excavation at Mohenjo-daro: Being an official account of archaeological excavations at Mohenjo-daro carried out by the Government of India between the years 1927 and 1931. Munshiram Manoharlal.

Mackay, E. J. H. (2001). The Indus Civilization. Sang-e-Meel.

Marshall, J. (Ed.). (1931/2012). Mohenjo-daro and the Indus Civilization: Being an Official Account of Archaeological Excavations at Mohenjo-daro carried out by Government of India between the years 1922 and 1927 ( $2^{\text {nd }}$ ed.). Culture Department, Pakistan.

Possehl, G. L. (2002). The Indus Civilization: A Contemporary Perspective. Vistaar.

Tokai University. (2000). Map of the Indus Civilization [Map]. https://www.researchgate.net/figure/Map-of-Greater-Indus-Valley-Civilizationadapted-from-Tokai-University-2000_fig2_329600632

UNESCO. (1964). Preservation of the Monument of Mohenjo Daro, Pakistan.

Wheeler, S. M. (1997). The Indus Civilization. Sang-e-Meel. 
Appendix-I

List of journals and the total number of papers published on Mohenjodaro

\begin{tabular}{|l|l|c|c|c|}
\hline $\begin{array}{l}\text { S. } \\
\text { No. }\end{array}$ & Research Journal - Title & Articles & $\begin{array}{c}\text { Reports and } \\
\text { Others }\end{array}$ & Total \\
\hline 1 & Journal of the Pakistan Historical Society & 2 & 1 & 3 \\
\hline 2 & Pakistan Archaeology & 3 & 3 & 6 \\
\hline 3 & Ancient Pakistan & & 2 & 2 \\
\hline 4 & Sindh Annual & & 1 & 1 \\
\hline 5 & Sindh Quarterly & 3 & 1 & 4 \\
\hline 6 & Sindhological Studies & 4 & & 4 \\
\hline 7 & The Grassroots & 2 & & 2 \\
\hline 8 & Journal of Asian Civilizations & 6 & 3 & 5 \\
\hline 9 & Lahore Museum Bulletin & 6 & & 9 \\
\hline 10 & The Archaeological Review & 2 & & 2 \\
\hline 11 & Ancient Sindh & 7 & 2 & 9 \\
\hline 12 & Sindh Antiquities & 39 & 14 & 53 \\
\hline \multicolumn{1}{|l|}{ Total } & & & 6 \\
\hline
\end{tabular}


Appendix-II

List of Abbreviations

AHDL Ahmad Hassan Dani Library, Taxila Institute of Asian Civilizations, Quaid-i-Azam University, Islamabad

AHDSL Prof. Emeritus Ahmad Hassan Dani Seminar Library, Department of Archaeology, University of Peshawar, Khyber Pakhtunkhwa

BHL Bait-al Hikmah Library (Central Library), Hamdard University (Main Campus), Karachi

CAL Central Archaeological Library, Federal Department of Archaeology and Museums, Government of Pakistan, 57 Hafiz Plaza, Shahrah-i-Faisal near Baloch Colony Overhead Bridge, Karachi

CLQAU Dr. Raziuddin Siddiqi Memorial Library (Central Library), Quaid-i-Azam University, Islamabad

CLUS Central Library, University of Sindh, Jamshoro, Sindh

DASALU Library, Department of Archaeology and Anthropology, Shah Abdul Latif University, Khairpur, Sindh

DOAM Publication section, Federal Department of Archaeology and Museums, Government of Pakistan, Islamabad

IsMEO Institute of Middle and Far Eastern Studies, Rome

LML Lahore Museum Library, Lahore, Punjab

RLS Research Library, Institute of Sindhology, University of Sindh, Jamshoro, Sindh

RWTH Rheinisch-Westfalischen Technischen Hochschule Aachen

SEASL Sindh Exploration and Adventure Society, Library, Karachi

\section{Notes:}

${ }^{1}$ In a restricted sense of this study, these are all the papers including articles, reports, a book review, and a poem published on Mohenjodaro in Pakistani research journals.

${ }^{2}$ The sculpture of the ram is named after Hoshang Mahboubian - the owner of the antique.

${ }^{3}$ The correct inventory number of this seal is DK 2030 (see Mackay, 1938/1998, p. XCIX).

${ }^{4}$ See Mackay, 1938/1998, p. XCIX.

${ }_{6}^{5}$ See Dales, 1964, p. 38-43.

${ }^{6}$ Indus River is shifting westward towards the remains.

${ }^{7}$ Justice Feroze Nana was the chairman of the National Committee for the Preservation of Moenjodaro.

${ }^{8}$ See Bhattacharjee and Bhattacharya, 2007, p. 48-49.

${ }^{9}$ See Jairazbhoy, 1988, p. 8-9.

${ }^{10}$ This author calls them as because three of them are reproduced from previous works and have no references and the remaining one is also reproduced and is poorly referenced. 